\title{
Artikel
}

\section{Het nieuwe Wetboek van Strafvordering. Hoe verder?}

\author{
Prof. mr. P.A.M. (Pieter) Verrest*
}

\section{Inleiding}

Eind juli 2020 is op de website van het ministerie van Justitie en Veiligheid een voorlopige versie van het nieuwe Wetboek van Strafvordering gepubliceerd. ${ }^{1}$ Midden in de zomervakantie; een grote gebeurtenis zou zo bijna onopgemerkt voorbijgaan.

Omdat de openbaarmaking niet werd toegelicht, was het voor buitenstaanders een beetje gissen naar de reden waarom die plaatsvond. Inmiddels is de reden duidelijk: het wetgevingstraject ${ }^{2}$ staat al enige tijd stil. ${ }^{3}$ Dat komt door het ontbreken van zicht op voldoende financiering

Pieter Verrest is hoogleraar straf(proces)recht, in het bijzonder Europees en internationaal strafrecht, Erasmus School of Law. Van 2018 tot medio 2020 was hij programmadirecteur modernisering Wetboek van Strafvordering bij de Directie Wetgeving en Juridische Zaken van het Ministerie van Justitie en Veiligheid. Hij is tevens redacteur van Boom Strafblad.

1. Ambtelijke versie juli 2020 van Wetsvoorstel tot vaststelling van Boeken 1 tot en met 6 van het nieuwe Wetboek van Strafvordering.

2. Met wetgevingstraject bedoel ik hier het traject dat begint met het concipiëren van een concept-voorstel, en vervolgens de fasen kent van formele consultatie, bespreking in ambtelijk voorportaal, besluitvorming door de ministerraad, advisering door de Raad van State en schriftelijke en mondelinge behandeling door beide Kamers van de Staten-Generaal. Het wetgevingstraject is hier tot stilstand gekomen na de stap 'formele consultatie'. Inmiddels zijn echter (samen met de betrokken organisaties uit de strafrechtspraktijk) wel de consultatieadviezen verwerkt (in de ambtelijke versie) en wordt intussen - met de praktijkorganisaties - volop doorgewerkt aan het concept-wetvoorstel voor de Innovatiewet Strafvordering, het opstellen van de AMvB's onder het nieuwe Wetboek en de concept-Invoeringswet met daarin het overgangsrecht.

3. Zie zesde voortgangsrapportage Kamerstukken II 2020/21, 29279 nr. 625, p. 3. Dit was eerder gemeld in de vijfde voortgangsrapportage, Kamerstukken I/ 2018/19, 29 279, nr. 501. voor de implementatie van het nieuwe Wetboek van Strafvordering - als die implementatie na het resterende deel van het wetgevingstraject over een jaar of zes uiteindelijk aan de orde is. In de zesde voortgangsrapportage is uitgelegd dat wat betreft het vinden van financiering de hoop is gevestigd op het volgende kabinet. ${ }^{4}$ Maar dan moesten politieke partijen uiteraard wel in staat zijn om kennis te nemen van het concept, zodat ze de modernisering konden opnemen in hun verkiezingsprogramma's - hetgeen inmiddels is gebeurd.

We zouden kunnen stellen dat het nieuwe Wetboek van Strafvordering zich in een kritische tussenfase bevindt. $\mathrm{Er}$ is geld nodig om een volgende stap te kunnen zetten. Het volgende kabinet zal hierover moeten beslissen. Volgens de Commissie implementatie nieuw Wetboek van Strafvordering (commissie-Letschert), die ondertussen onderzoek heeft verricht naar de implementatiekosten, gaat het om een bedrag tussen de 292 en 360 miljoen euro. ${ }^{5}$ Een enorm bedrag. Dat kan leiden tot twijfel: is het allemaal wel de moeite waard?

In dat kader wil ik in deze bijdrage - inmiddels van enige afstand - kijken naar nut en noodzaak van het nieuwe Wetboek van Strafvordering. Als daar positief over wordt geoordeeld, is een minstens even belangrijke vraag voor het komende kabinet hoe het traject op een kansrijke wijze zou kunnen worden voortgezet. Ook daar wil ik kort op ingaan. vordering, p. 10. 


\section{Nut van het nieuwe Wetboek van Strafvordering}

Sinds 2014 is door wetgevingsjuristen van het ministerie van Justitie en Veiligheid en experts van de organisaties uit de strafrechtspraktijk intensief samengewerkt om te komen tot een volledig gemoderniseerd Wetboek van Strafvordering (hierna kortweg: Wetboek). Het huidige Wetboek is 100 jaar geleden tot stand gekomen, en hoewel het nog steeds functioneert, wordt de basis die het biedt voor de criminaliteitsbestrijding en de rechtspleging zo langzamerhand wankel.

Wie gewend is aan ons huidige Wetboek en begint te bladeren in de voorlopige versie van het nieuwe Wetboek, wordt meteen getroffen door het verschil. Het nieuwe Wetboek is toegankelijk, overzichtelijk en het geeft richting. Artikelen volgen elkaar in logische volgorde op. De rechtsregels zijn actueel: ze zijn afgestemd op de huidige praktijk van opsporing en strafrechtspleging in onze moderne samenleving. Uitvoerige rechtspraak over tal van onderwerpen is verwerkt, zodat het weer zin heeft om het Wetboek ter hand te nemen voor het geldende recht voor het doorzoeken van een smartphone, de omgang met het verschoningsrecht, het responderen op verweren ter zitting en de sancties op vormverzuimen. Iedere bepaling is doorgenomen en waar nodig inhoudelijk verbeterd met het oog op de werkzaamheid in het licht van een efficiënte opsporing en adequate rechtsbescherming. Eveneens heel belangrijk: alle artikelen van het Wetboek worden van een uitgebreide uitleg voorzien in de memorie van toelichting.

Zoveel helderheid: dat zijn we helemaal niet gewend! Kijk bijvoorbeeld naar de regeling van de voorlopige hechtenis, naar de enorme vereenvoudiging van de regeling van bijzondere opsporingsbevoegdheden. Het geeft an hoezeer ons huidige Wetboek uit het lood is geraakt, en zijn belangrijkste functie, houvast bieden aan professionals en burgers, niet meer vervult. Het nieuwe Wetboek heeft nog meer te bieden: het is zoveel mogelijk toekomstbestendig. Het bevat een catalogus opsporingsbevoegdheden die is toegesneden op het verrichten van onderzoek in een volledig digitale omgeving. Nog belangrijker is dat het nieuwe Wetboek een techniekonafhankelijke regeling geeft voor alle momenten waarop communicatie tussen procesdeelnemers plaatsvindt of communicatie van strafrechtelijke organen met de burger - denk aan een toekomstig digitaal berichtenportaal. Hetzelfde geldt voor vastlegging van bevelen, de verslaglegging van onderzoekshandelingen en terechtzittingen. Zo kan dit allemaal rechtsgeldig geschieden op audiovisuele of andere niet-schriftelijke wijze. Deze kernprocessen in onze strafvordering hoeven dan in de toekomst niet meer in het Wetboek te worden aangepast om het gebruik van (telkens nieuwe) technologische ontwikkelingen mogelijk te maken.

Het nieuwe Wetboek brengt al deze verbeteringen op een manier die nauw ansluit op de bestaande rechts- praktijk, zodat die niet wordt geconfronteerd met grote veranderingen die de werkprocessen verstoren. Het nieuwe Wetboek lijkt op al deze punten dus zeker nuttig.

\section{Intermezzo: het bredere perspectief van werken aan een nieuw Wetboek}

Voor de duidelijkheid: wat voorligt is een voorlopige versie van het nieuwe Wetboek. Niet voor niets heet die 'ambtelijke versie': er heeft over de inhoud nog geen besluitvorming plaatsgevonden op politiek niveau. Kabinet en Kamer hebben zich nog niet uitgesproken over de inhoud van het nieuwe Wetboek van Strafvordering - anders dan aan het begin van het moderniseringsproces over de uitgangspunten vervat in de Contourennota. ${ }^{6}$ Dat moet allemaal nog komen. De ambtelijke versie kan worden gezien als het resultaat van de jarenlange gezamenlijke inzet van wetgevingsjuristen en experts van de praktijkorganisaties, begeleid door prof. mr. G. Knigge als adviseur en voorzien van wetenschappelijke input van de Commissie modernisering Wetboek van Strafvordering. De ambtelijke versie is een soort informeel compromis over een tekst die als vertrekpunt kan dienen voor de advisering door de Raad van State over het concept-nieuwe Wetboek. Niet meer en niet minder. Na de advisering door de Raad van State breekt weer een nieuwe fase aan. Die van het politieke debat, amendering, aanvulling, inkleuring. De betrokken praktijkorganisaties zijn in die fase van het wetgevingstraject wederom volop in de gelegenheid om in het debat te participeren en hun eigen wensen op de voorgrond te plaatsen.

Maar goed, het traject ligt dus stil. De commissie-Letschert steekt haar mening daarover niet onder stoelen of banken: het traject moet zo snel mogelijk vlot worden getrokken. ${ }^{7}$ Het kabinet heeft tot dusver echter geen mogelijkheid gezien om de financiële horde te nemen die de stilstand veroorzaakt. Even over de horde zelf. Op grond van de Comptabiliteitswet mag een conceptwetsvoorstel niet worden voorgelegd aan de ministerraad en voor advies worden aangeboden aan de Afdeling advisering van de Raad van State zonder sluitende begroting voor de incidentele (implementatie-) en structurele kosten die het wetsvoorstel oplevert. Doel is om financiële debacles te voorkomen. De regel is op zich begrijpelijk, maar past niet zo goed op een omvangrijk, langdurig en uniek wetgevingstraject dat moet leiden tot een nieuw algemeen Wetboek. Over de kosten van de implementatie van het Wetboek van Strafvordering valt een groot aantal jaren voordat die implementatie daad-

6. Kamerstukken I/ 2015/16, 29279, nr. 278 (Contourennota) en nr. 314 (Algemeen overleg).

7. Advies van de Commissie implementatie nieuw Wetboek van Strafvordering, Den Haag 2020, p. 3-4. 
werkelijk aan de orde zal zijn, slechts in termen van schattingen met grote bandbreedtes wat te zeggen. ${ }^{8}$

Wat betreft die financiering hielp het niet dat het nieuwe Wetboek van Strafvordering niet als onderwerp was opgenomen in het regeerakkoord voor het huidige kabinet. ${ }^{9}$ Het kabinet formuleert in een regeerakkoord een aantal doelstellingen en wil daarover aan het einde van een kabinetsperiode verantwoording (kunnen) afleggen. Het is om die reden niet echt logisch dat een kabinet trajecten inzet die consequenties hebben voor een volgend kabinet, tenzij die trajecten als het ware door een zittend kabinet voorgefinancierd zouden worden. Tijdens een kabinetsperiode komen echter allerlei kleine en grotere onderwerpen op die ook de aandacht van het kabinet behoeven - denk daarbij in de huidige kabinetsperiode aan de intensivering van de aanpak van ondermijnende drugscriminaliteit na de moord op advocaat Derk Wiersum. Daarvoor moeten ook financiële middelen beschikbaar zijn.

De vraag is wel gesteld waarom de praktijk niet sterker aandringt op modernisering van het Wetboek van Strafvordering. Het klopt dat we het OM, de politie, de Rechtspraak en de advocatuur tot dusver niet op de barricaden hebben gezien voor het nieuwe Wetboek van Strafvordering. ${ }^{10}$ Maar moeten we daaruit afleiden dat zij het belang van een nieuw Wetboek niet onderschrijven? Het lijkt mij begrijpelijk dat zij hun aandacht in eerste instantie richten op andere, urgentere kwesties. Bijvoorbeeld: hoe kunnen we, ondanks bezuinigingen, met schaarse middelen blijven instaan voor de kwaliteit van de strafrechtspraktijk en en passant voldoen aan de immer toenemende hoeveelheid 'speerpunten' en 'prioriteiten'? ${ }^{11}$ De aandacht gaat terecht uit naar vandaag en morgen. Het nieuwe Wetboek is voor overmorgen of erna.

De burger dan? Zou die gewicht in de schaal kunnen leggen? Dat is moeilijk. De burger begrijpt met wat goede uitleg waarom de strafbaarstelling van verkrachting zou moeten worden aangepast. ${ }^{12}$ En ook dat er $(\mathrm{nog})^{13}$ meer mogelijkheden voor het afpakken van crimineel geld moeten komen, om te zorgen dat misdaad

8. Zie Commissie implementatie nieuw Wetboek van Strafvordering, 2020, p. 9-12. Dit komt voornamelijk doordat de praktijkorganisaties nog geen zicht hebben op hun ICT-structuur op die termijn, noch op de exacte omvang van (de opleidingsmogelijkheden van) hun personele bezetting.

9. In het Regeerakkoord 2017 'Vertrouwen in de toekomst' is enkel op p. 6 opgenomen: "De positie van het slachtoffer blijft een speerpunt, in het bijzonder bij de herijking van het Wetboek van Strafvordering".

10. Zie echter recent (8 januari 2021) bijvoorbeeld het interview met de Voorzitter van het College van PG's Van der Burg (www.strafrechtketen.nl).

11. Zie Trouw 30 januari 2021, 'Politie, $O M$ en rechtspraak willen 850 miljoen voor sterke rechtsstaat. "De verwachting dat zaken snel worden afgehandeld, kunnen wij nu niet waarmaken".'

12. Kamerstukken // 2020/21, 34843, nr. 44.

13. Kamerstukken // 2020/21, 29911, nr. 297. Wie tussen de regels van het verhaal over juridische lacunes doorleest, begrijpt dat het gaat om het zoeken naar de gemakkelijkste manier van afpakken, omdat vervolging wegens witwassen te bewerkelijk wordt gevonden en ontnemingszaken te lang duren. niet loont. De burger zal een positief gevoel hebben bij de aankondiging dat er structureel geld wordt vrijgemaakt voor honderden extra ${ }^{14}$ rechercheurs voor een nieuwe multidisciplinaire antidrugseenheid. ${ }^{15}$ Voor de burger blijft echter het nut van een gemoderniseerd Wetboek van Strafvordering zonder sterke boodschap te abstract.

Conclusie van dit alles: het nieuwe Wetboek van Strafvordering is nuttig, maar dat is niet genoeg. Er is overtuigingskracht nodig. Om ermee verder te gaan moet de noodzaak van de wetgevingsoperatie worden gevoeld.

\section{De noodzaak van het nieuwe Wetboek}

Waarom is het werken aan een nieuw Wetboek ooit begonnen? We lijken het vergeten. Toch kan de directe aanleiding met een paar muisklikken worden gevonden. In 2012 constateerde de Algemene Rekenkamer dat de prestaties in de strafrechtketen in veel opzichten slecht waren. Veel strafzaken werden niet opgepakt en bij de zaken die wel de strafrechtketen doorliepen, was sprake van lange doorlooptijden voordat het tot een afdoening kwam. ${ }^{16}$ De reactie van de toenmalige Minister van Veiligheid en Justitie was duidelijk:

'Een van de belangrijkste maatregelen die een positieve bijdrage levert aan vrijwel alle doelstellingen (PV: meer zaken succesvol afronden, verkorting doorlooptijden, digitale informatie-uitwisseling in de keten en met de advocatuur en de burger etc.) is de herstructurering van (kern-)onderdelen van het Wetboek van Strafvordering en andere wetgeving. De wetgeving wordt ingezet om de regels en lasten te verminderen en zal een bijdrage leveren aan de versnelling van de doorlooptijden, het verminderen van administratieve lasten, de vereenvoudiging en stroomlijning van procedures en het digitaliseren van de strafrechtsketen.' ${ }^{\prime 7}$

Geldt die analyse nog steeds? Of is de situatie een aantal jaren later dermate verbeterd dat een nieuw Wetboek geen toegevoegde waarde meer heeft? Nou nee, recent verrichte PWC een doorlichting van de strafrechtketen

14. Helaas lijkt hier - net als in het nabije verleden bijvoorbeeld bij de uitbreiding van het aantal financieel rechercheurs - sprake van een neiging tot kannibalisme: de nieuwe dienst trekt andere onderdelen van de politie of bijzondere opsporingsdiensten leeg, zodat de capaciteitsuitbreiding voor de opsporing uiteindelijk gering is. Zie M. Haenen, 'Politie ruziet over aanpak misdaad', NRC/Handelsblad 22 januari 2021.

15. Kamerstukken I/ 2020/21, 29911, nr. 292.

16. Algemene Rekenkamer, Prestaties in de strafrechtketen, Den Haag 2012. Dit rapport werd korte tijd later gevolgd door een onderzoek van AEF, Ongewenste uitstroom in de strafrechtketen. Oorzaken en oplossingen, 2013 dat dezelfde conclusies kende.

17. Kamerstukken // 2012/13, 29279, nr. 165, p. 8-9. 
in opdracht van de Brede Bestuursraad ${ }^{18}$ van het ministerie van Justitie en Veiligheid. ${ }^{19}$ De situatie die een tiental jaren geleden zorgen opriep, is op punten verbeterd maar toch grotendeels onveranderd: het aantal onderzoeken naar ondermijning is iets toegenomen maar het gevoel van te weinig capaciteit voor aanpak van allerlei soorten criminaliteit blijft, de doorlooptijden zijn bij kleine en grote strafzaken wellicht iets verbeterd maar zijn nog steeds lang. ${ }^{20}$ De samenwerking in de keten moet veel beter. En er is ondanks allerlei onderzoeken, herhaalde beloftes en veel geïnvesteerd geld nog steeds niet één digitale backbone, een softwaremodule waarin alle organen samen efficiënt aan zaken kunnen werken. ${ }^{21}$

Dat komt overeen met het beeld dat in de stukken over de modernisering van het Wetboek van Strafvordering te lezen valt ${ }^{22}$ en waarvoor - op het niveau van de wet in het nieuwe Wetboek oplossingen zijn bedacht. Aan de lange doorlooptijden in strafzaken valt veel te doen door het aantal gevallen waarin de rechter een zaak moet aanhouden omdat het onderzoek nog niet is afgerond, terug te dringen; dat terugwijzen kost namelijk veel tijd. ${ }^{23}$ In de regeling van het strafproces in het nieuwe Wetboek wordt ingezet op een bemeging naar voren. De gedachte is dat zaken beter moeten worden voorbereid voordat de rechter met de berechting begint. Daarvoor wordt ruimte gecreëerd in het opsporingsonderzoek, door de duur daarvan niet formeel te limiteren (in geval van een voorlopig gehechte verdachte). De rechter-commissaris krijgt meer tijd om op vordering van de officier van justitie of op verzoek van de verdediging nader onderzoek te verrichten met het oog op de volledigheid en evenwichtigheid van het dossier. De raadsman van de verdachte krijgt ter ondersteuning het recht om bij getuigenverhoren van de rechter-commissaris aanwezig te zijn en heeft ruime toegang tot de processtukken. Wanneer het opsporingsonderzoek is afgerond, volgt eerst een procesinleiding, waarna de voorzitter van de rechtbank zich in overleg met de partijen nogmaals buigt over de volledigheid van het onderzoek. Daarna volgt pas de inhoudelijke behandeling van de zaak. ${ }^{24}$

18. Daarin zijn vertegenwoordigd de directeuren-generaal van het ministerie Justitie en Veiligheid, de Nationaal Coördinator Terrorisme en Veiligheid, het openbaar ministerie, de Dienst Justitiële Inrichtingen, de Immigratie- en Naturalisatiedienst en de Nationale Politie.

19. PWC, Doorlichting Strafrechtketen. Nieuwe uitdagingen vragen om optimalisatie van samenwerking, juni 2020 (Bijlage bij Kamerstukken II 2019/20, 29279, nr. 264). Vooropgesteld moet worden dat de conclusies van het onderzoek niet heel helder zijn en ook allerlei vragen oproepen. In die zin geven ze een waarheidsgetrouw beeld van een weerbarstige strafrechtketen en gefragmenteerde sturing.

20. PWC 2020, Bijlage, p. 13.

21. PWC 2020, p. 12

22. Kamerstukken I/ 2018/19, 29279, nr. 501, p. 8-16 (Update Contourennota).

23. Zie o.a. ook M. Dubelaar, R. van Leusden, J. ten Voorde en S. van Wingerden, Alleen voor de vorm? Frequentie, organisatie en praktijk van pro-formazittingen, Den Haag: WODC 2015.

24. Memorie van toelichting bij het wetsvoorstel tot vaststelling van het nieuwe Wetboek van Strafvordering, p. 26-28.
Hierboven heb ik al gewezen op de catalogus opsporingsbevoegdheden toegesneden op onderzoek in een digitale omgeving. Daarnaast bevat het nieuwe Wetboek een sterk vereenvoudigde regeling van de bijzondere opsporingsbevoegdheden; bij veel bijzondere opsporingsbevoegdheden zijn wijzigingen doorgevoerd om toepassing eenvoudiger te maken - zoals verlenging van toepassingstermijnen. Ook is voorzien in de mogelijkheid van generieke bevelen voor het vorderen van gegevens. Dit alles komt ten goede aan een effectieve opsporing.

Indien we in de nabije toekomst een einde willen maken aan het geschuif met stapels papier in de strafrechtketen (onterecht wordt gedacht dat er inmiddels digitale dossiers zijn: feitelijk gaat het over telkens opnieuw in het eigen ICT-systeem van de volgende betrokken ketenorganisatie ingescande papieren kopieën), hebben we een Wetboek nodig dat technologische vernieuwing, digitale vastlegging, audiovisuele verslaglegging en communicatie via een berichtenportaal mogelijk maakt. Dat doet het nieuwe Wetboek met techniekonafhankelijke regelgeving.

Als we dit weten, is niets doen toch eigenlijk geen optie? Enerzijds horen we dat rechters overbelast zijn ${ }^{25}$ en dat de politie het water over de schoenen loopt bij de opsporing van ondermijnende drugscriminaliteit. ${ }^{26}$ Dat de gefinancierde rechtsbijstand door bezuinigingen is verschraald. ${ }^{27}$ Anderzijds zijn er dus mogelijkheden om met gemoderniseerde wetgeving de opsporingsinstanties hun schaarse capaciteit effectiever te laten inzetten en overbelaste rechters en advocaten beter in staat te stellen om hun werk te doen. De toegevoegde waarde van 100 extra rechercheurs is in verhouding gering als die niet optimaal kunnen werken. Het enthousiasme over de slag die de politie heeft kunnen toebrengen aan de georganiseerde misdaad met de EncroChat en Sky ECC hacks zou wel eens heel wat minder kunnen worden als de afwikkeling van de daaruit resulterende strafzaken wegens lange doorlooptijden in de rechtspraak verzandt. Het nieuwe Wetboek kan op al deze punten zorgen voor verbetering. ${ }^{28}$ Leg dát de burger uit!

25. F. Jensma, De overbelaste rechtbank, NRC/Handelsblad 21 november 2019.

26. De verontrustende waarheid over aanpak drugscriminaliteit in Brabant: We gaan het zo niet redden', Bd 29 juni 2019.

27. Commissie evaluatie puntentoekenning rechtsbijstand, Andere tijden. Evaluatie puntentoekenning in het stelsel van gesubsidieerde rechtsbijstand, 2017 (bijlage bij Kamerstukken I/ 2017/18, 31753, nr. 142).

28. Zie interview met W. van de Donk (voorzitter van het Bestuurlijk Ketenberaad) in Binnenlands Bestuur, 7 oktober 2020, die in antwoord op de vraag 'Er gaan wel structureel vele tientallen miljoenen naar het landelijke MIT en de dienst Bewaken en Beveiligen, bleek uit de begroting van Justitie en Veiligheid, maar slechts eenmalig 15 miljoen euro naar de regionale en lokale aanpak. Wat is uw reactie daarop?' zegt: 'Het verdedigen van de rechtsstaat, het idee van een eerlijke samenleving, mag ons wat geld kosten, en er is ook al het nodige gebeurd. Het Pact voor de Rechtsstaat mikt op 400 miljoen euro structureel voor de volgende kabinetsperiode. De aanpassing van het Wetboek voor Strafvordering lijkt mij echter meer bepalend dan geld (mijn cursivering, PV). Er is de afgelopen jaren veel capaciteit ingeleverd, en je hebt niet zomaar nieuwe mensen opgeleid." 
De kernboodschap moet zijn: het kabinet wil voor de burger investeren in een efficiënte criminaliteitsbestrijding en een goede strafrechtspleging. Dat gebeurt met een nieuw Wetboek van Strafvordering dat daarvoor de basis legt. ${ }^{29}$

Is dat het hele verhaal? Nee, nog niet. Want het zou niet eerlijk zijn om te doen alsof de noodzakelijke verbeteringen door enkel invoering van een nieuw Wetboek zouden kunnen worden gerealiseerd. Alle praktijkorganisaties benadrukken dat in hun adviezen over het nieuwe Wetboek. In het bijzonder de advocatuur heeft consequent - en beeldend - gewezen op het feit dat flankerend beleid net zo belangrijk is als een nieuw Wetboek. ${ }^{30}$ Neem de verbeteringen die het nieuwe Wetboek wil bewerkstelligen met de bemeging naar voren. Die beweging zal alleen slagen als de verdediging erin meegaat. Dat kan zeker gebeuren, maar dan moet de verdediging wel in de gelegenheid worden gesteld om de voordelen die vroegtijdige inzet in de zaak voor haar biedt, te realiseren. Zo heeft de advocaat formeel toegang tot de processtukken, maar in de praktijk moet hij daarvoor veel inspanningen verrichten. Dat is in één keer afgelopen als er een digitaal zaakbehandelingssysteem zou zijn waartoe hij toegang heeft. Het stelsel van gefinancierde rechtsbijstand moet zo worden ingericht dat een raadsman al tijdens het opsporingsonderzoek voldoende extra uren kan besteden aan het doornemen van het dossier en het formuleren van onderzoeksvragen. En heel basaal: er moet voor worden gezorgd dat - aan de overzijde - de officier van justitie de tijd heeft om de telefoon op te nemen als de raadsman contact met hem zoekt, en dat de rechter-commissaris voldoende capaciteit heeft om de door hem toegewezen onderzoekswensen uit te voeren. ${ }^{31}$

Het is dus en-en. De voortzetting van het traject van het nieuwe Wetboek van Strafvordering moet gepaard gaan met een serieuze investering in de strafrechtsketen. Anders heeft de wetgevingsoperatie minder zin en zal die niet op veel enthousiasme kunnen rekenen. Dat is het eerlijke verhaal, en the may formard.

\section{Hoe dan? The way forward}

Dankzij het werk van de commissie-Letschert is het moderniseringsproces behoed voor een Catch 22-situatie: geen budget en onduidelijkheid over wat de implementatie op termijn kost. Dat laatste is nu opgelost. In het verlengde heeft het nieuwe Wetboek door het

29. Dit is in de kern een legitimiteitskwestie. De acceptatie van de burger van de zorg van de overheid voor een veilige samenleving is gestoeld op het vertrouwen dat de overheid daartoe alle middelen inzet die nodig zijn.

30. Zie o.a. P.T.C. van Kampen, D.V.A. Brouwer, L. van Lent en M.C. van Wijk, Mind the gap. Modernisering Wetboek van Strafvordering: consequenties voor de verdediging, 2018, p. 250-252, 262-263, 270-277.

31. Advies NOvA op de Contourennota modernisering Wetboek van Strafvordering, p. 6. onderzoek van de commissie voorzichtig een plaats gekregen in de verkiezingsprogramma's van politieke partijen. $^{32}$

In de kern schetst de commissie dezelfde may formard: via uitleg van het nut en de noodzaak van het Wetboek. Bij uitleg van de noodzaak wordt door de commissie ook het voorbeeld van de betere zaaksvoorbereiding door de beweging naar voren gebruikt. $Z$ ij verbindt hieraan ook de conclusie dat flankerende maatregelen moeten worden getroffen, zoals aanpassing van het stelsel van gefinancierde rechtsbijstand aan de beweging naar voren $^{33}$ en een voor alle actoren toegankelijk digitaal procesdossier. ${ }^{34} \mathrm{Zij}$ wijst daarnaast ook op de mogelijkheden die efficiënter werken kan bieden in de zin van structurele baten. ${ }^{35}$

De analyse dat er efficiënter gewerkt kan worden - en dat het nieuwe Wetboek dat gaat faciliteren - klopt. Voorkomen moet worden dat die structurele baten worden ingeboekt als 'terugverdieninkomsten' voor de kosten van de implementatie. Ideeën voor stroomlijning van procedures in het nieuwe Wetboek zouden op die manier juist negatief kunnen uitpakken voor de organisaties in de strafrechtspraktijk, omdat de gewonnen efficiëntie dan dreigt uit te monden in (verdere) bezuinigingen. Het is logisch dat de strafrechtspraktijk dat wil voorkomen. Indien dezelfde vernieuwingen niet in de sleutel worden geplaatst van kostenbesparing, kunnen ze voor een enorme boost aan energie zorgen. Nieuwe wetgeving die efficiënter werken mogelijk maakt, geeft tijd om het werk goed te doen en tijd om meer zaken op te pakken. Van zo'n vooruitzicht wordt iedere professional in de strafrechtelijke praktijk enthousiast ${ }^{36}$

Het is verheugend dat uit de verkiezingsprogramma's van politieke partijen de wil naar voren komt om breder te investeren in de criminaliteitsbestrijding en in de strafrechtspleging. Dat zou in ieder geval moeten gebeuren door versterking van de gefinancierde rechtsbijstand en door de tekorten bij de rechtspraak aan te zuiveren (onder gelijktijdige herbezinning op het systeem van outputfinanciering), en verder door eindelijk één digitaal zaakbehandelingssysteem te realiseren voor alle bij de strafrechtspleging betrokken organen. Een digitale backbone, waarin alle processtukken zijn te vinden en waarin iedere procesdeelnemer direct zijn bijdrage kan leveren. ${ }^{37}$ Juist die combinatie van een

32. In de verkiezingsprogramma's van VVD, CDA, D66, PvdA, CU.

33. Commissie implementatie nieuw Wetboek van Strafvordering, p. 12

34. Commissie implementatie nieuw Wetboek van Strafvordering, p. 8.

35. Commissie implementatie nieuw Wetboek van Strafvordering, p. 8-9.

36. Het is niet voor niets dat grootschalige wetgevingsoperaties op strafrechtelijk terrein in landen om ons heen altijd lijken te worden gepresenteerd als onderdeel van een kwalitatieve investering in de criminaliteitsbestrijding en de strafrechtspleging. Zie P.A.M. Verrest, Frankrijk, in: P.A.M. Verrest en P.A.M. Mevis (red.), Rechtsvergelijkende inzichten voor de modernisering van het Wetboek van Strafvordering, Den Haag: Boom 2018, p. 224.

37. Nederland loopt hier in verhouding met andere Europese landen behoorlijk achter. Zie A.H. Klip, C. Peristeridou en D.L.F. de Vocht, Citius, altius, fortius - Sneller, hoger, sterker. Wat we van Engeland en 
modern Wetboek van Strafvordering en een gedigitaliseerde strafrechtketen maakt $1+1=3$.

Net als de voortzetting van het wetgevingstraject van het nieuwe Wetboek en de voorbereiding van de implementatie - zoals de commissie-Letschert benadrukt ${ }^{38}$ vergt het voltooien van de digitalisering van de strafrechtketen regie. Die regierol moet de overheid op centraal niveau oppakken: dat vloeit voert uit haar taak om ervoor te zorgen dat de organisaties in de strafrechtspraktijk goed hun werk kunnen doen.

\section{Tot slot}

Het nieuwe Wetboek van Strafvordering gaat ongetwijfeld bij het grote publiek meer leven als het politieke debat over het Wetboek op gang komt. Met de ambtelijke versie van het nieuwe Wetboek ligt er een goede basis voor dat politieke debat. Een uitgebreid inhoudelijk debat is nodig om de regeling van het strafprocesrecht in het nieuwe Wetboek de nodige democratische legitimiteit te geven. De concept-wetgeving kan worden aangepast, aangevuld en ingekleurd. We moeten in dat verband niet vergeten dat het parlementaire debat over ons huidige Wetboek in de jaren 10 en 20 van de vorige eeuw een behoorlijk aantal jaren in beslag nam. ${ }^{39}$

Waar zou het politieke debat over het nieuwe Wetboek van Strafvordering over kunnen gaan? Op welke terreinen liggen bij uitstek nog politieke keuzes voor? Ik wil daar tot besluit van deze bijdrage een paar woorden aan wijden.

Kijkend naar de politieke actualiteit ligt het voor de hand dat aandacht zal uitgaan naar de positie van het slachtoffer in het strafproces. In de ambtelijke versie is de positie van het slachtoffer beter beschreven en zijn de rechten van het slachtoffer in het strafproces uitgebreid door het mogelijk maken van beklag tegen niet-opsporing. Ook bevat de ambtelijke versie - zij het nog tussen haken - de mogelijkheid voor de zittingsrechter om een complexe vordering benadeelde partij van het slachtoffer af te splitsen en te laten behandelen door een aparte (strafrechtelijke) schadevergoedingskamer. ${ }^{40}$ Het is voorstelbaar dat in het Kamerdebat wordt gesproken over verdere uitbreiding van rechten voor het slachtoffer. Dan zou het volgende in overweging kunnen worden genomen. Het afgelopen decennium heeft het slachtoffer steeds meer rechten gekregen, deels door implementatie van EU-regelgeving. Een sterke, dogmatisch verankerde positie van het slachtoffer, waarop die verschillende rechten hadden kunnen worden gebouwd en op grond waarvan die hadden kunnen worden geor-

Duitsland kunnen leren in het kader van modernisering strafvordering, Den Haag: WODC 2019, p. 67-74 en 86 over Duitsland.

38. Commissie implementatie nieuw Wetboek van Strafvordering, p. 4.

39. Zie voor de inhoud van het brede debat over ons huidige Wetboek van Strafvordering o.a. Handelingen // 1917/18, 77, nr. 1.

40. Memorie van toelichting, p. 789-800, i.h.b. 789-790. dend, ontbrak echter in het Wetboek van Strafvordering. Dit heeft (mede) ertoe geleid dat thans verschillende soorten rechten en hoedanigheden van het slachtoffer door elkaar lopen: het slachtoffer is procesdeelnemer én procespartij (in de zin van benadeelde partij); het slachtoffer is getuige die een verklaring aflegt én spreekgerechtigde; het slachtoffer is spreekgerechtigde ten aanzien van de feiten én spreekgerechtigde die zich uitlaat over de straftoemeting c.q. de vordering benadeelde partij. ${ }^{41}$ Dat leidt in de rechtszaal tot verwarring van hoedanigheden en tot teleurstelling bij het slachtoffer. Dat zou kunnen worden voorkomen door een knip aan te brengen tussen de uitoefening van rechten van het slachtoffer vóór en na schuldigverklaring van de verdachte, in een lichte vorm van een tweefasenproces. $^{42}$

Een tweede onderwerp dat mijns inziens in het Kamerdebat aandacht zou verdienen is dat van de berechting. De regeling van het strafprocesrecht in het nieuwe Wetboek staat in het model van het contradictoir strafproces. Dat is een bewuste keuze: dit komt overeen met het huidige recht en er lijkt in de praktijk en in de wetenschap weinig behoefte aan verandering. ${ }^{43}$ Het contradictoir strafproces past goed bij het pragmatisme en het streven naar proceseconomie: twee kenmerken van de rechtsvorming op strafvorderlijk terrein in Nederland.

Goed beschouwd leunt het contradictoir proces zwaar op het kwalitatief presteren van de procesdeelnemers. ${ }^{44}$ Er zijn relatief weinig checks and balances in de procedure van vooronderzoek en tijdens de berechting. De vraag is of op deze manier voldoende waarborgen bestaan voor adequate rechtsbescherming in het algemeen en het waken voor justitiële dwalingen in het bijzonder. De beweging naar voren is in dit opzicht pure winst: de rechter-commissaris heeft meer tijd voor het uitoefenen van controlerende bevoegdheden in het vooronderzoek; en na het uitbrengen van de procesinleiding volgt in een tussenfase regie onder leiding van de voorzitter van de rechtbank. ${ }^{45}$ Daartegenover staat dat in het nieuwe Wetboek ook voorstellen worden gedaan die leiden tot minder checks and balances, zoals het doorvoeren van het voortbouwend appel en het verder terugtreden van de Hoge Raad (mogelijkheid afzien van nemen conclusie door PG). ${ }^{46}$ Het zou in die zin overweging

41. Zie ook Y. Buruma, 'Het gemoderniseerde Wetboek van Strafvordering: de Boeken 3 tot en met 6 . Enige onorthodoxe reflecties', RM Themis 2018/5, p. 174-175.

42. Een inventarisatie van mogelijk passende oplossingen is te vinden in B.F. Keulen, A.A. van Dijk, E. Gritter, N.J.M. Kwakman en K. Lindenberg, Naar een tweefasenproces? Over voor- en nadelen van een strafproces in twee fasen, in relatie tot de posities van slachtoffer en verdachte, Den Haag: WODC 2013, p. 324

43. Zie Kamerstukken II 2015/16, 29 279, nr. 278, p. 6.

44. Dat is niet zonder risico. Zie in dit verband over de officier van justitie, Y. Buruma 2018, p. 169; over de verdediging Brouwer e.a., p. 264-265. Zie verder o.a. P.A.M. Verrest, Raison d'être. Een onderzoek naar de rol van de rechter-commissaris in ons strafproces, Den Haag: Boom 2011, p. 217-279.

45. Zie ook J.M. Reijntjes, 'De procesinleiding. Het goede moment voor regie', Platform Modernisering Strafvordering, februari 2020.

46. Vgl. Memorie van toelichting, p. 839-840. 
verdienen om nog eens goed te kijken naar de berechting in eerste aanleg en deze te spiegelen aan de berechting in het Duitse strafproces. ${ }^{47}$ In het Duitse recht ligt een sterkere nadruk op het onmiddellijkheidsbeginsel: de verdachte moet aanwezig zijn om hem te kunnen berechten, indien mogelijk verklaren getuigen op zitting, en de zittingsrechter behandelt stap voor stap de bewijsmiddelen. Dat leidt tot meer transparantie tijdens de berechting en mogelijkheden voor controle voor de verdediging.

Een ander punt van overweging betreft het verder onderzoeken van de mogelijkheden voor verkorte afdoening van zaken - onder regie van de rechter - op grond van de procesopstelling van de verdachte. Wederom het Duitse recht, maar ook het Franse recht, ${ }^{48}$ biedt voorbeelden van hoe de wijze van afdoening kan worden aangepast aan een bekennende verdachte. ${ }^{49}$ Ook daarover zou het debat kunnen worden gevoerd.

Kortom: het nieuwe Wetboek van Strafvordering is nuttig omdat het professionals en burgers weer houvast geeft met een gemoderniseerde en op de toekomst voorbereide regeling van het strafprocesrecht. De noodzaak van het nieuwe Wetboek van Strafvordering ligt in het feit dat het alle betrokken organen in staat stelt om veel beter en efficiënter te werken bij de opsporing en de berechting van misdrijven. Maar daarvoor moeten wel ook de financiële tekorten van advocatuur en rechtspraak worden aangepakt en moet de digitalisering van de strafrechtketen met strakke regie worden volbracht. Zin heeft het nieuwe Wetboek dus pas echt als de invoering onderdeel is van een bredere kwalitatieve investering in de strafrechtelijke praktijk. Tot slot zal het nieuwe Wetboek ongetwijfeld echt gaan leven als het voorwerp wordt van parlementair debat.

47. Uitgebreid belicht door P.A.M Mevis, Duitsland, in Verrest en Mevis 2018, p. 114-126. Zie ook L. van Lent, A. Smolders en M. Malsch, ‘We kennen allemaal de stukken...', DD 2020/38.

48. P.A.M. Verrest, 2018, p. 204.

49. Zie Klip e.a., 2019, p. 84-85 en verder o.a. B.F. Keulen, 'Strafrechter en consensualiteit', DD 2014/71. Zie ook L.J.J. Peters, ‘De regisserende rechter; een goede deal?', Strafblad 2015/32. 